\title{
The effectiveness of new drugs for mastitis treatment in cows in lactation and dry period
}

\author{
Vladimir Komarov ${ }^{1 *}$, Boris Belkin ${ }^{1}$, Vladimir Masalov ${ }^{1}$, Sergey Andreev ${ }^{2}$ and \\ Anna Gutsyna ${ }^{3}$ \\ ${ }^{1}$ Oryol State Agrarian University named after N.V. Parakhin, 69, 302019, General Rodin st., Oryol, \\ Russia \\ ${ }^{2}$ Scientific Research Institute of Disinfectology, 117246,18, Nauchny proezd, Moscow, Russia \\ ${ }^{3}$ Oryol State University named after I.S. Turgenev (95, Komsomolskaya st., Oryol, \\ 302026, Russia)
}

\begin{abstract}
The available bibliographic sources on the study of the veterinary drugs use effectiveness for mastitis treatment in cows in various physiological periods are analyzed. The use of anti-mastitis drugs for lactating and dry cows' treatment is highlighted. Mastitis incidence in cows and relative study of the treatment mode for mastitis in the lactation and dry periods with the use of new drugs developed by Oryol SAU in cooperation with Experimental and Technological Company Etris, LLC is analyzed. In the experiment, the therapeutic efficacy of new anti-mastitis drugs was found to be 5-6\% higher compared to those used on the farm. For high therapeutic efficacy, dosage scheme to be strictly followed, which will reduce the material costs for treatment.
\end{abstract}

\section{Introduction}

Dairy cattle breeding is an important link in the economic development of the farming sector. In modern requirement of dairy stockbreeding, illness in cattle cause essential economic loss to complex. Thus, obstetric and gynecological pathology, breast inflammation (mastitis) and diseases of the distal extremities are the most common pathologies. The frequency of each pathology in animals increases due to the intensification of milk production, concentration of animals groups in limited areas, violating sanitary and hygienic standards for animal housing, an increase in the milk productivity of cows and others. Mastitis is recorded regularly in groups at dairy units and farms around the world. Disease incidence is in the range of 5 to $50 \%$ of the dairy herd, and in some herds is even higher.

Milk, as is well known, is one of the full-fledged food products created by nature itself and widely used in both children's and dietary nutrition. A large range of dairy products using in food of people is prepared from high-quality dairy raw materials. At all times, milk was valued for its amazing nutritional properties. Milk is used as a therapeutic and preventive agent in many diseases treatment. According to the data of many researchers,

\footnotetext{
*Corresponding author: komarov.volodya@yandex.ru
} 
during lactation most valuable and essential elements are released from the animal's body, which certainly leads to the weakening and exhaustion of the animal. Such a manifestation is especially dangerous for high-producing cows with intensive milk production, because the higher lactation performance, the more the animal gives useful vital substances. Therefore, it is very important to get high-quality milk, which largely depends on cows health. The quality of milk is affected by numerous factors, primarily the quality and level of feeding, veterinary hygiene, selected and genetic work, as well as drugs and methods of preventive medical care[4, 5, 6].

Mastitis at dairy cattle breeding company in the Oryol region is widely distributed, according to some sources the disease incidence is rising up to $20-25 \%$ or more of the dairy drove of cows The manifestation of pathology in a cow contributes to a decrease in milk productivity during lactation by $10 \%$, with deprecation of milk and risk increase of released and spread dangerous microorganisms with milk, premature cow disposal, and diarrhea syndrome in calves. The inflammation of the mammary gland (mastitis) is a disease with a variable etiology $[1,2,3,10,11]$.

As many studies indicate, mastitis develops as a result of the pathogenic microorganisms' penetration into the mammary gland. Staphylococcus, Escherichia coli, Streptococci, Bacillus bacteria and other were found during the bacteriological study of udder secretions in the studied farms $[4,5,6]$.

Unfortunately, when using many anti-mastitis drugs, the desired therapeutic effect is not always provided. This is due to the fact that the antibiotic sensitivity of infectious agents is reduced.In this regard, it is recommended to schedule of anti-mastitis drugs use at dairy units [2, 3].

Therefore, the research objectives include the study of the pathology prevalence and the analysis of the treatment regimens for this pathology with the use of new therapeutic drugs.

\section{Material and methods}

The research was conducted in accordance with state research programs.

The therapeutic efficacy of anti-mastitis drugs and their application schemes was studied in production conditions at Oryol milk production facilities on cows with different forms of mastitis. In the experiment, there were animals of black-and-white Holstein and Simmental breeds, which were selected in groups on the principle of analogues.

Diagnostic studies in cows for inflammation in the mammary gland were carried out according to the generally accepted method in accordance with the Instructions. The study of the sanitary quality of milk was carried out in the university laboratory and at milk production facilities.

The subclinical form of mastitis was detected using a rapid mastitis test (RMT). To do this, the secret of the mammary gland of cows was mixed with diagnosticums: kenotest, dimastin, mastidine, masttest. Additionally, a sedimentation test was performed. Laboratory microbiological studies of udder secretions were performed. The diagnosis of the clinical form of mastitis was carried out visually by the nature of the obtained secretion from the lacteous gland.

Statistical analysis of the data obtained during the experiment was carried out in a specialized program Microsoft Excel. 


\section{Results and discussion}

When examining cows at milk production facilities, it was found that mastitis was detected in 48 animals $(22.6 \%)$ out of 212 cows examined at two dairy farms; 43 cows $(20.3 \%)$ had a subclinical form of mastitis, and $5(2.3 \%)$ - clinical (Figure 1).
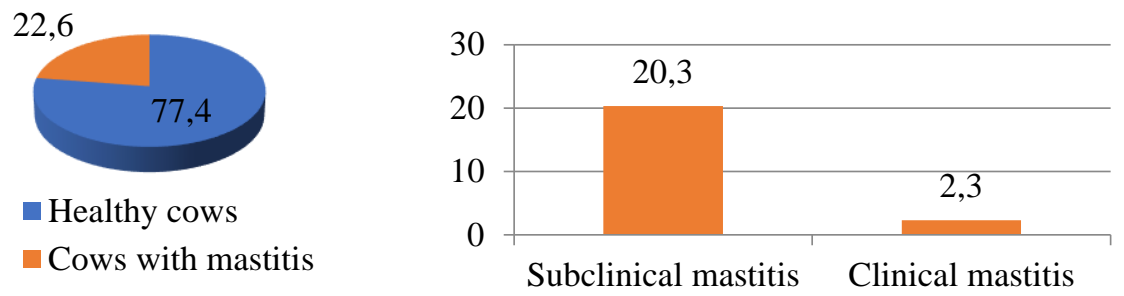

Fig. 1. Mastitis incidence in cows in the studied herds, $\%$.

The spread of the pathological process was established depending on the lesion of the udder lobes. It turned out that 22 cows or $45.8 \%$ of the total number of cows in the herd were found with pathology of one udder lobe, 14 (29.2\%) with two lobes, 10 (20.8\%) with three lobes, and two cows (4.2\%) with damage to all four udder lobes (Figure 2).

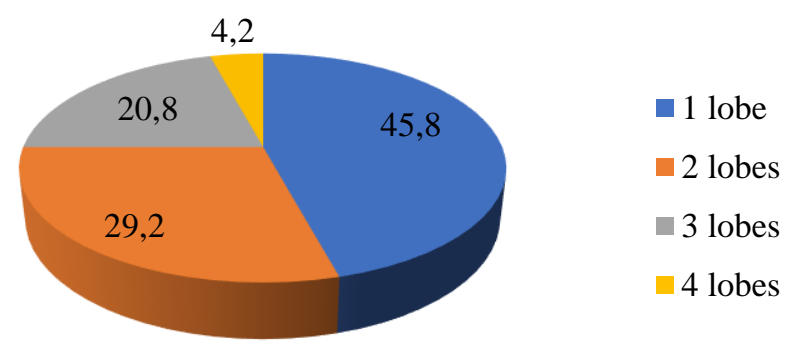

Fig. 2. Affected udder lobes of cows with mastitis in the dairy drove, $\%$.

Generalized data on the incidence of lactating cows with mastitis on dairy farms are also presented in Table 1.

Table 1. Mastitis incidence in lactating cows.

\begin{tabular}{|c|c|c|c|c|c|c|c|c|c|c|c|}
\hline \multirow{2}{*}{\multicolumn{2}{|c|}{ Indicator }} & \multicolumn{2}{|c|}{1 group } & \multicolumn{2}{|c|}{2 group } & \multicolumn{2}{|c|}{3 group } & \multicolumn{2}{|c|}{4 group } & \multicolumn{2}{|c|}{ In herd } \\
\hline & & $\begin{array}{c}\text { head } \\
\text { s }\end{array}$ & $\%$ & $\begin{array}{c}\text { head } \\
\text { s }\end{array}$ & $\%$ & $\begin{array}{c}\text { head } \\
\text { s }\end{array}$ & $\%$ & heads & $\%$ & $\begin{array}{c}\text { head } \\
\text { s }\end{array}$ & $\%$ \\
\hline \multicolumn{2}{|c|}{$\begin{array}{c}\text { Number of } \\
\text { examined cows }\end{array}$} & 56 & 100 & 57 & 100 & 50 & 100 & 49 & 100 & 212 & 100 \\
\hline \multirow{3}{*}{ 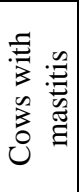 } & Total & 11 & 19,6 & 14 & 24,6 & 10 & 20 & 13 & 26,5 & 48 & 22,6 \\
\hline & $\begin{array}{l}\text { Subclinic } \\
\text { al case }\end{array}$ & 9 & 16,1 & 12 & 21,1 & 10 & 20 & 12 & 24,5 & 43 & 20,3 \\
\hline & $\begin{array}{c}\text { Clinical } \\
\text { case }\end{array}$ & 2 & 3,5 & 2 & 3,5 & - & - & 1 & 2 & 5 & 2,3 \\
\hline \multirow{4}{*}{ 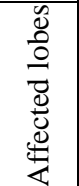 } & 1 lobe & 3 & 27,3 & 6 & 42,9 & 5 & 50 & 8 & 61,5 & 22 & 45,8 \\
\hline & 2 lobes & 4 & 36,4 & 4 & 28,6 & 3 & 30 & 3 & 23,1 & 14 & 29,2 \\
\hline & 3 lobes & 3 & 27,3 & 3 & 21,4 & 2 & 20 & 2 & 15,4 & 10 & 20,8 \\
\hline & 4 lobes & 1 & 9 & 1 & 7,1 & - & - & - & - & 2 & 4,2 \\
\hline
\end{tabular}


Various opportunistic and pathogenic microorganisms play a major role in the development of the mammary gland inflammation.

Figure 3 shows the microorganisms isolated during the bacteriological study of secretion samples of the mammary gland taken from mastitis-affected udder lobes in the Oryol region farms.

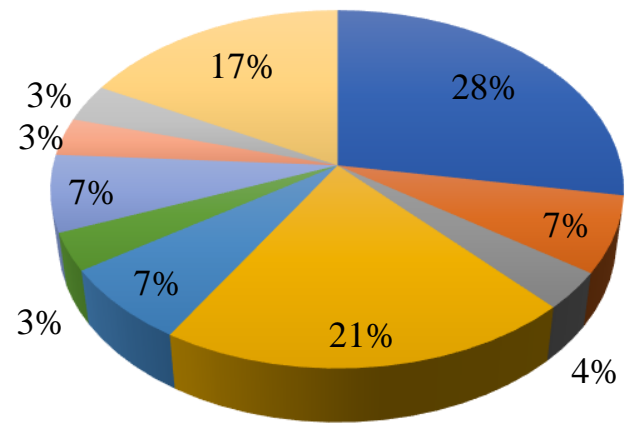

\author{
- Streptococcus agalaetiae \\ - Staphylococcus aureus \\ - Staphylococcus hominis \\ - Streptococcus dysgalaetiae \\ - Staphylococcus haemolyticus \\ - Staphylococcus saprophyticus \\ - Staphylococcus epidermidis \\ Escherichia Coli \\ Clostridium perfringens \\ Грибы рода Candida
}

Fig. 3. Structure of isolated microorganisms in mastitis cow in farms, $\%$.

Treatment of dry cows. The dry period is an important link in the preparation of the cow for the next lactation. In dry period, the intrauterine development of the fetus is completed, preparation for calving takes place, and lacteous glandular tissue is renewed. The dry period allows to prevent many diseases in cows. It is very important to cure the animal during this period, so that after calving to get high-quality colostrum, necessary for calf rearing.

Therefore, it is necessary to treat and prevent cow's mastitis in the dry period. Currently, a large number of methods and medicines for mastitis treatment in cows of various forms are known, including antimicrobial drugs.

Scientists of Oryol SAU in cooperation with Experimental and Technological Company Etris, LLC have developed anti-mastitis drug containing the antibacterial substance - the antibiotic apramycin in combination with xanthan gum at the ratio, $\% \mathrm{wt}$ : apramycin -5.0 10.0, xanthan gum - 0.25-1.0, distilled water is the rest up to 100 .

Apramycin is an aminoglycoside antibiotic (aminocyclitol) that has a large spectrum of antimicrobial activity.

Xanthan gum is a high-molecular polysaccharide that has the ability to stabilize solutions, retain moisture and provide a thickening effect.

The complex combination of substances provides an increase in therapeutic efficiency, achieving the necessary density of the solution, reducing the risk of side effects, safety for mastitis treatment in cows and prevents the extension of the inflammatory process.

For the study some experimental groups of cows were selected. Two groups of cows, one with clinical and one with subclinical mastitis, were treated with the used drug dienomast, and the other two groups of cows (one with clinical and one with subclinical mastitis) - according to the developed method using a new drug.

The drugs were administered once after the last evening milking to the cows during their drying-off. Initially, the remaining milk was milked from the udder lobes. Then the udder teats were disinfected with swabs wetted with alcohol. The secretion isolated from the affected lobes was disposed. The drugs were heated to $37^{\circ} \mathrm{C}$ and shaken before administration until a homogeneous solution was formed. The syringe was pressed tightly against the external opening of the nipple canal, the drug was injected in the dose of $10 \mathrm{ml}$ 
into teat udder cistern by gently pressing the plunger of the syringe. A light massage of the udder was performed from the bottom up after administration of the drug.

Based on the results of the conducted drug tests, their high therapeutic efficacy was established. However, the new anti-mastitis drug, which contains apramycin and xanthan gum, both in subclinical mastitis and in clinical mastitis, provided higher therapeutic efficacy (Table 2).

Table 2. Results of cow mastitis treatment in dry period.

\begin{tabular}{|c|c|c|c|c|c|c|}
\hline \multirow[b]{2}{*}{ Drug } & \multicolumn{3}{|c|}{ Subclinical mastitis } & \multicolumn{3}{|c|}{ Clinical mastitis } \\
\hline & $\begin{array}{l}\text { Treated } \\
\text { cows / } \\
\text { udder } \\
\text { lobes }\end{array}$ & $\begin{array}{l}\text { Cured } \\
\text { cows / } \\
\text { udder } \\
\text { lobes }\end{array}$ & $\begin{array}{l}\text { Percentage of } \\
\text { cured cows / } \\
\text { udder lobes }\end{array}$ & $\begin{array}{l}\text { Treated } \\
\text { cows / } \\
\text { udder } \\
\text { lobes }\end{array}$ & $\begin{array}{l}\text { Cured } \\
\text { cows / } \\
\text { udder } \\
\text { lobes }\end{array}$ & $\begin{array}{c}\text { Percentage of } \\
\text { recovered } \\
\text { cows / udder } \\
\text { lobes }\end{array}$ \\
\hline Dienomast & $16 / 32$ & $15 / 31$ & $93,7 / 96,8$ & $16 / 34$ & $14 / 32$ & $87 / 94,1$ \\
\hline New drug & $5 / 16$ & $5 / 16$ & $100 / 100$ & $16 / 32$ & $16 / 32$ & $100 / 100$ \\
\hline
\end{tabular}

Mastitis treatment in cows during lactation should be aimed at ensuring high therapeutic efficacy and simultaneously at reducing the amount of milk rejected due to the development of mastitis and the use of anti-mastitis drugs.

An anti-mastitis drug has been developed for treatment in lactation period, which contains an antimicrobial substance-dioxidine and additionally lactam tetramethylenetetramine, methyluricyl, xanthan gym and distilled water.

Dioxidin is a domestic antimicrobial drug with a broad spectrum of action on bacterial strains.

Lactam tetramethylenediethylenetetramine is a substance that has the ability to penetrate microbial cells and block their matrix-genetic function.

Methyluricil is an immunostimulating drug that has anabolic activity and accelerates the processes of cell regeneration.

In experiment on testing therapeutic regimens for mastitis in cows, four groups of animals were selected. Two were treated with Difumast, and the other two were treated with a new drug (Table 3).

According to the therapeutic regimens of cows, the drugs were used after evening milking. The remaining milk was milked from the affected udder lobes. Then the udder teats were disinfected with swabs wetted with alcohol. The secretion isolated from the affected lobes was disposed. The drugs were administered to the affected lobes at a dose of $10 \mathrm{ml}$ once a day until the animal was fully recovered. After drug administration, a light massage of the udder nipple was performed from the bottom up.

Table 3. Results of cows' treatment with known and proposed drug in lactation.

\begin{tabular}{|c|c|c|c|c|c|c|}
\hline \multirow{2}{*}{ Drug } & \multicolumn{3}{|c|}{ Subclinical mastitis } & \multicolumn{3}{c|}{ Clinical mastitis } \\
\cline { 2 - 7 } & $\begin{array}{c}\text { Treated } \\
\text { cows / } \\
\text { udder } \\
\text { lobes }\end{array}$ & $\begin{array}{c}\text { Cured } \\
\text { cows / } \\
\text { udder } \\
\text { lobes }\end{array}$ & $\begin{array}{c}\text { Percentage of } \\
\text { cured cows / } \\
\text { udder lobes }\end{array}$ & $\begin{array}{c}\text { Treated } \\
\text { cows / } \\
\text { udder } \\
\text { lobes }\end{array}$ & $\begin{array}{c}\text { Cured } \\
\text { cows / } \\
\text { udder } \\
\text { lobes }\end{array}$ & $\begin{array}{c}\text { Percentage } \\
\text { of } \\
\text { recovered } \\
\text { cows / } \\
\text { udder lobes }\end{array}$ \\
\hline Difumast & $7 / 14$ & $5 / 11$ & $71,4 / 78,5$ & $10 / 25$ & $6 / 19$ & $60 / 76$ \\
\hline New drug & $7 / 13$ & $6 / 11$ & $85,7 / 84,6$ & $10 / 26$ & $7 / 21$ & $70 / 80,7$ \\
\hline
\end{tabular}

When analyzing the data obtained as a result of the experiment on testing a new antimastitis drug, it was found that the therapeutic efficacy of the new drug is higher than that of the used one by 5-6\%. 


\section{Conclusions}

Mastitis incidence in cows at the milk production facility was $22.6 \%$, of which $20.3 \%$ had a subclinical form and $2.3 \%$ had a clinical form of mastitis. Effective methods of mastitis treatment in cows have been developed. So for mastitis treatment in cows in the dry period, a drug containing apramycin in combination with xanthan gum was used. The drug is administered intracisternally after the last evening milking before transferring to the dryresistant group in an amount of $10 \mathrm{ml}$ once. For mastitis treatment in cows during in lactation, a drug containing dioxydine, xanthan gum, tetramethylenetetramine lactam and methyluricyl was used. The drug, depending on the degree of the lesion, is used up to three times with an interval of 24 hours until the affected udder lobe is completely cured. The use of the developed anti-mastitis drugs provides high therapeutic efficacy.

\section{References}

1. V.B. Andreev, B.L. Belkin, L.S. Gromov, T.E. Ilyin, V.Yu. Komarov, A brief guide for the prevention of mastitis, limb diseases of cattle and sanitary care of milking equipment (Kaluga: Publishing House: OOO Noosfera), 104 (2017)

2. B.L. Belkin, V.Yu. Komarov, V.B. Andreev, Mastitis of cows (Publishing House LAP LAMBERT Academic Publishing), 113 (2015)

3. B.L. Belkin, V.N. Masalov, T.V. Popkova, E.N. Skrebneva, N.A. Malakhova, V.Yu. Komarov, Recommendations for improving the quality of milk in the Orel region (Orel, Orel SAU), 31 (2014)

4. K. Hameed, G. Sender, A. Korwin-Kossakowska, Public health hazard due to mastitis in dairy cows. Animal Science Papers and Reports 25073085 (2006)

5. G.A. Larionov, N.I. Shirkunova, Modern means for processing the udder of cows (Cheboksary, Publishing House: Chuvash State Agricultural Academy) 176 (2020)

6. G.A. Larionov, O.U. Checheneshkina, N.V. Mardaryeva, M.G. Terentyeva, V.G. Semenov, N.K. Kirillov, A.Yu. Lavrentiev, Measures for reducing the bacterial content and the number of somatic cells in cows milk. Materials of the International Scientific and Practical Conference 037039 (2019)

7. O. Sampimon, H. Barkema, I. Berends, J. Sol, T. Lam, Prevalence of intramammary infection in Dutch dairy herds. Journal of Dairy Research 76129136 (2009)

8. Y. Schukken, D. Wilson, F. Welcome, L. Garrison-Tikofsky, R. González, Monitoring udder health and milk quality using somatic cell counts. Journal of Veterinary Research 34579596 (2003)

9. A.M. Skogoreva, O.A. Manzhurina, O.V. Popova, S.N. Semenov, A.V. Aristov, Improving treatment of subclinical cow mastitis using miramistin antiseptic agent. IOP Conference Series: Earth and Environmental Science. 6th International Conference on Agriproducts Processing and Farming 012045 (2020)

10. B. Tenhagen, G. Köster, J. Wallman, W. Heuwieser, Prevalence of mastitis pathogens and their resistance against antimicrobial agents in dairy cows in Brandenburg, Germany. Journal of Dairy Science 8925422551 (2006)

11. N.A. Berezina, A.V. Artemov, I.A. Nikitin, A.A. Budnik, International Journal of Advanced Computer Science and Applications. 10 (5), 137-143 (2019) 